\title{
Note on a New Parasitic Copepod, Caligus brevis n. sp.
}

\author{
Sueo M. Shinno \\ Faculty of Fisheries, Mie Prefectural University
}

The new Caligid Copepod to be described below was found on the body surface of the fishes of Labridae taken on the coast of Hamazima; Mie Prefecture, last summer. Other specimens belonging to the same species were discovered from the bottle, in which the fishes of Blenniidae and Scorpaenidae, collected at Sirahama, Wakayama Prefecture, were preserved. An exact record on the host name is, accordingly, lacking in this case. Both the lots are retained in Mie Prefectural University*.

\section{Caligus brecis n. sp.}

Hosts and specimens: Found on the body surface of 3 species of Labridae at Hamazima : 20 ovigerous and 6 non-ovigerous females and 14 males on Pseudolabrus japonicus (Houttuyn); 5 ovigerous and 5 non-ovigerous females and 6 males on Duymaeria flagellifera (C. \& V.) ; 1 non-ovigerous female on Halichoeres poecilopterus (T. \&S.). From Sirahama, 4 ovigerous females and a male. Following descriptions are based on a female and a male on the first named host from Hamazima.

Transparent, colorless, but sparsely spotted with brown pigment all over the body, eye brown, and egg strings pale pinkish. Entire length of female including egg strings $4.55 \mathrm{~mm}$, body excluding caudal rami $3.08 \mathrm{~mm} \times 1.85 \mathrm{~mm}$, egg strings $1.71 \mathrm{~mm}$ long; male excluding caudal rami $2.48 \mathrm{~mm} \times 1.53 \mathrm{~mm}$ (Figs. 1 \& 2).

Female: Stumpy. Carapace $2 / 3$ the length of body, as long as wide, with largest diameter at posterior $1 / 3$ of its own length, and well curved on sides. Frontal plates a trifle wider than than half the entire width, with a short spinule just inside the lunule of each side. Cephalic area slightly shorter than thoracic area and with eye about its centre. Transverse groove slightly arched forwards and longitudinal ones divergent backwards. Median lobe extending back beyond lateral lobes, with evenly round margin, but somewhat angular at each corner. Sinuses oval, open backwards. Fourth thoracic segment very short, $1 / 4$ as wide as carapace, contracted in front, and entirely fused behind with genital segment, though demarked from it by insigni-

Received February 2, 1954.

* This is a part of the results of the studies progressed by the financial aid from the Scientific Research Fund of the Department of Education. 


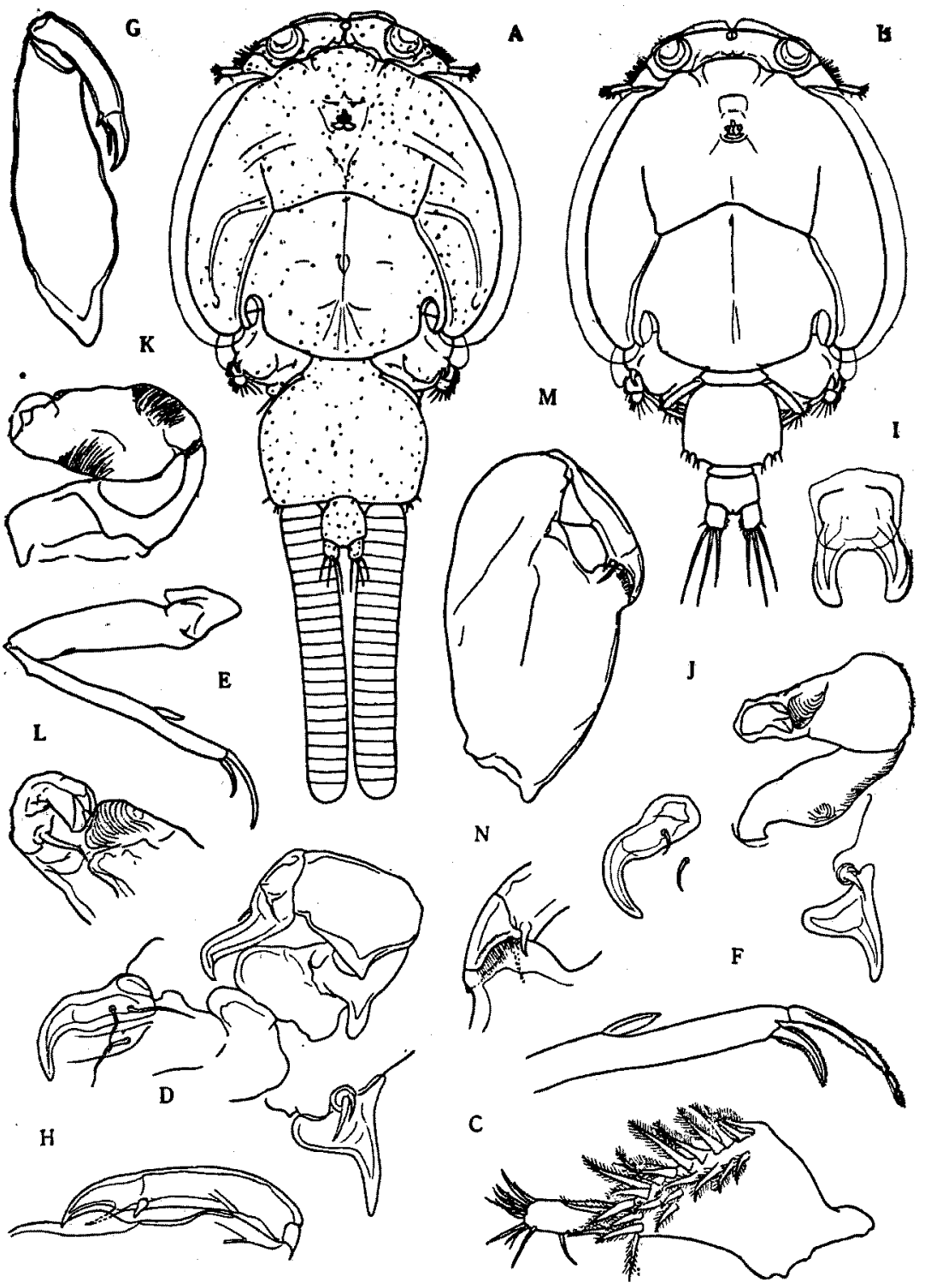

Fig. 1. Caligus brevis n. sp.

A, female, dorsal view; B, male, dosal view; C-I, female; C, Ist antenna, ventral view; $D, 2$ 2nd antenna, 1st and 2nd maxillae in situ; E, 1st maxilliped; F, thp of same; G, 2nd maxilliped; H, same, finger and inner margin of palm, further enlarged; I, sternal fork; J-N, male; J, 2nd antenna, 1st and 2nd maxillae in situ; K, 2nd antenna, anterior face; L, tip of same, further enlarged; $M$, 2nd maxilliped; $N$, same, tip of finger and tubercle on palm, further enlarged.

A $\times 21, \mathrm{~B} \times 24, \mathrm{C}, \mathrm{D}, \mathrm{G}, \mathrm{I}-\mathrm{K} \times 108, \mathrm{E} \times 75, \mathrm{~F}, \mathrm{H}, \mathrm{N} \times 153, \mathrm{~L} \times 186, \mathrm{M} \times 92$. 
ficant notches just back of limb bases. Genital segment about 2/5 as long as carapace, wider than long, being widest at anterior $1 / 3$ of its length. It rapidly narrows forwards from the widest region, having well-curved margins, but only slightly backwards with straight sides. Posterior border insensibly emarginate, ending in angular corner on either side. Abdomen $2 / 5$ as long as preceding segment, longer than wide, somewhat narrowed in front, and V-shaped behind. Egg strings slightly shorter than carapace.

First antennae with relatively long plumose spines on basal joint. Claw of 2nd antennae with curved apex and 2 short spinules as usual; basal joint carrying blunt, unguiform posterior process. First maxillae bent at a right angle; 2nd maxillae with broad base and filiform apex. Distal joint of 1st maxillipeds provided, a short distance behind its tip, with an apically pointed, foliaceous lobe. Palm of 2nd maxillipeds $1 / 3$ as broad as long, fusiform, with an inconspicuous, lunular crest about the centre of inner border. Finger not much curved, closing down past the named crest on palm, and carrying 2 spinules. Branches of sternal fork lanceolate, concave towards each other, forming together an incomplete ring which embraces a circular central space; their apices blunt and their bases united into a quadrangle. Numbers and arrangement of spines and setae, with which 4 pairs of natatories are armed, will be shown by the following table:**

\begin{tabular}{|c|c|c|c|c|c|c|c|c|c|c|}
\hline \multirow{2}{*}{$\operatorname{Lcg}$} & \multirow{2}{*}{ Border } & \multirow{2}{*}{$\begin{array}{l}\text { Sternal } \\
\text { plate }\end{array}$} & \multicolumn{2}{|c|}{ Protopodite } & \multicolumn{3}{|c|}{ Exopodite } & \multicolumn{3}{|c|}{ Enclopodite } \\
\hline & & & I & II & I & II & III & I & II & III \\
\hline I & $\begin{array}{l}\text { outer } \\
\text { inner }\end{array}$ & & $\begin{array}{l}1 p \\
1 p\end{array}$ & & $\begin{array}{l}\text { lh } \\
\mathrm{c}\end{array}$ & $\begin{array}{l}4 \mathrm{~h} \\
3 \mathrm{Q}\end{array}$ & & & & \\
\hline II & $\begin{array}{l}\text { outer } \\
\text { inner }\end{array}$ & f & $1 P$ & $\begin{array}{l}\mathrm{f}, \mathrm{l}_{\mathrm{p}} \\
\mathrm{f}, \mathrm{l}_{\mathrm{s}}\end{array}$ & $\begin{array}{c}\mathrm{f}, \mathrm{IH} \\
\mathrm{c}, \mathrm{IP}, \mathrm{c}\end{array}$ & $\begin{array}{c}1 \mathrm{H} \\
\mathrm{c}, 1 \mathrm{P}\end{array}$ & $\begin{array}{c}2 \mathrm{H}, 1 \mathrm{Q} \\
5 \mathrm{P}\end{array}$ & $\begin{array}{l}c \\
1 P\end{array}$ & $\begin{array}{c}\mathrm{c} \\
\mathrm{c}, 2 \mathrm{P}\end{array}$ & $\begin{array}{r}c \\
6 \mathrm{P}\end{array}$ \\
\hline II & $\begin{array}{l}\text { outer } \\
\text { inner }\end{array}$ & f & $\begin{array}{c}f, 1 P \\
1 P, f, 2 s, c\end{array}$ & & $\begin{array}{c}1 H^{\prime}, c, 1 H \\
\text { IP }\end{array}$ & $\begin{array}{c}\text { c, } 3 \mathrm{H} \\
4 \mathrm{P}\end{array}$ & & $1 P$ & $c, c P$ & \\
\hline N & $\begin{array}{l}\text { outer } \\
\text { inner }\end{array}$ & & $I_{p}$ & & $1 \mathrm{H}$ & $3 \mathrm{H}$ & & & & \\
\hline
\end{tabular}

First legs with a short rudiment of endopodite. Plumose spines on apical joint bear a row of setae along inner border, while a narrow membrane, traversed by oblique striations, along outer border, retaining setae only in a short basal part. Terminal spines on the same joint slender, subequal in length, central 2 of them

* Abbreviations in the table: $c$, row of hairs; $f$, membraneous flange; $H$, longer spine; $h$, shorter spine, ; $\mathrm{H}^{\prime}$, hook-like spine; $\mathrm{P}$, longer plumose spine; $\mathrm{p}$, shorter plumose spine; $\mathrm{Q}$, spine hairy on one side, rimmed with membrane on the other; s, solitary hair. Roman numerals indicate the numerical orders of the legs, or of the joints, and Arabian ones the number of spines, or others present on each of them. 


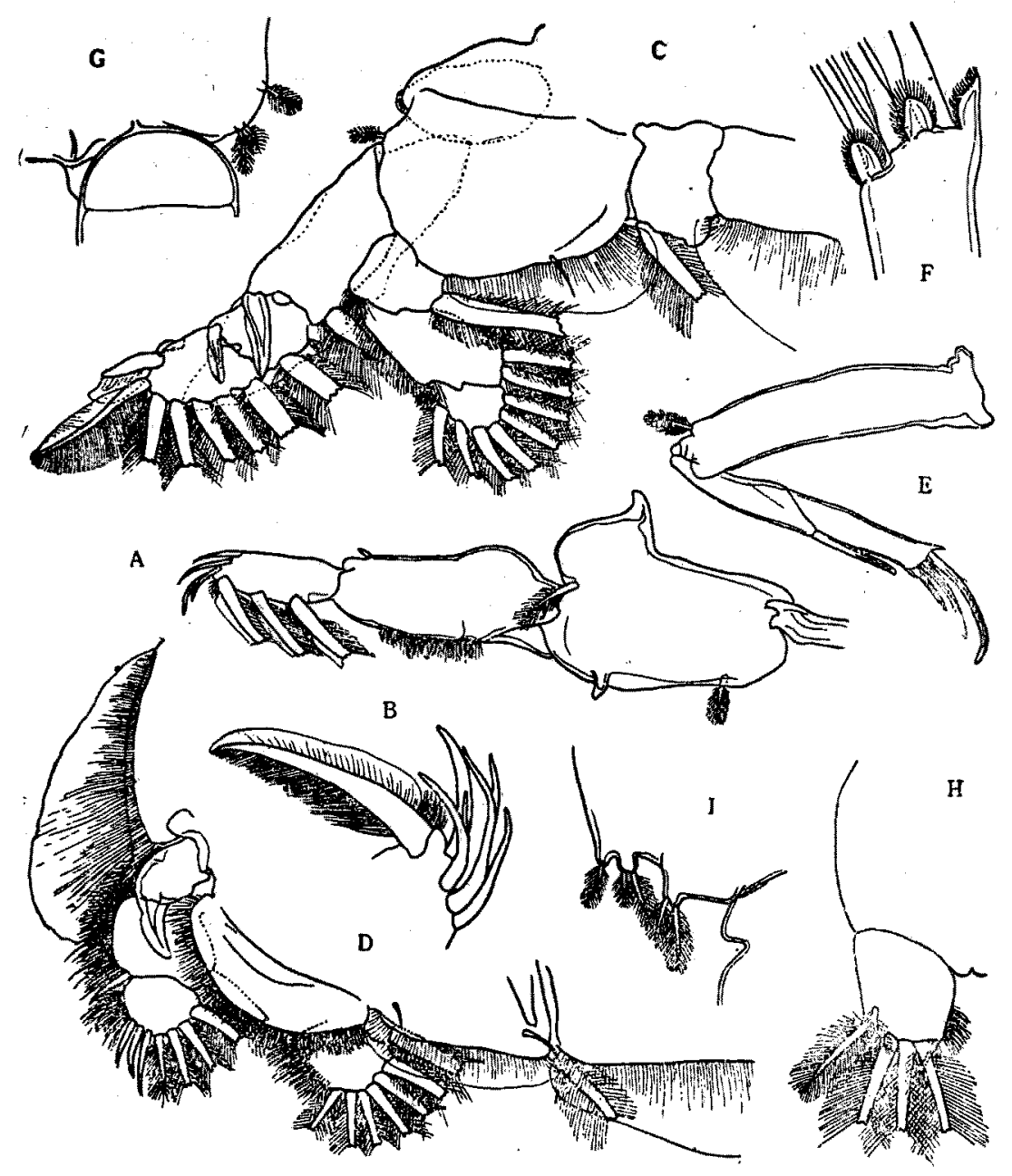

Fig. 2. Caligus brevis n. sp.

A-H, female ; A, 1st swimming leg; B, tip of same in Sirahama specimen, further enlarged; C, 2nd leg; D, 3rd leg; E, 4th legs; F, same, end of apical joint, further enlarged; $G$, postero -lateral region of genital segment, ventral view; $\mathrm{H}$, caudal ramus, ventral view; $I$, male, Fostero-lateral region of genital segment, ventral view.

A, C-E, H, I $\times 108 ; \mathrm{B} \times 330 ; \mathrm{F} \times 438 ; \mathrm{G} \times 75$. 
divided at their apices into 2 branches, closely appressed together. Of ext'rnzl spines on 3rd exopodite joint of 2 nd legs, basal one short, simple, succeeding one with a lunular rim on inner border, and terminal one much longer, rimmed on the outside, but setose on the inside. Exopodite of 3rd legs 2-jointed, somewhat apart from 1-jointed endopodite, whose basal joint is largely fused with protopodite; hook on the former with narrow external rim. Last legs short, 3-jointed. Terminal spines decrease in length successively from within outwards, the longest being more than twice the shortest; each of them accompanies at the base an oval, finely pectinate lamina. Spine on 2nd joint equals to the middle one on 3 rd joint in length, but lacks basal lamina. Genital segment has 2, short, plumose spines at each postero-lateral angle and another similar one on lateral margin a little forwards; it is doubtful if they represent 5 th leg rudiments. Caudal rami short, as long as broad, armed with 3 longer and 3 shorter plumose spines; the latter lot arranged 2 at outer distal angle and 1 at inner angle. Inner border of the rami ciliated.

Male: Shorter than female. Carapace and 4th thoracic segment resembling those of that sex in outline, but the latter distinct from succeeding segment and with wedgeshaped sides. Genital segment quadrate, $1 / 4$ as long as carapace, and a little shorter than its own width. Two sides almost parallel, but curved inwards at anterior ends. Posterior border serrated on either side, bearing 3 conical papillae arranged side by side; outermost of them tipped by a short, plumose spine, and others by 2 . Abdomen half as long as genital segment, wider than long, somewhat narrowing forwards, 2-segmented; 1st segment transversely linear like 4th thoracic, but smaller; 2nd quadrilateral, with distinct anal papillae.

Terminal joint of posterior antennae a stubby claw, having broad end, rugged surface, and a short, basal spine. Second joint raised on ventral surface near the end to form a triangular bulge, covered with parallel striations; it has further 2, similar areas on anterior face, one along upper border close to the base, and the other along lower border about the middle. Basal joint also striated along lower border on posterior face. Falm of 2 nd maxillipeds obovate, harf as wide as long, inner border with an eminent, molar-like protuberance, carrying a small, acuminate secondary process at the hind end. Finger thick, strong, and with 2 spinules, which hold between themselves the named protuberance of palm. Caudal rami as in female, but with longer spines. Otherwise as in that sex.

Remarks: Sirahama specimens are smaller than those described above, the largest female measuring $2.68 \mathrm{~mm} \times 1.08 \mathrm{~mm}$ and the male $2.03 \mathrm{~mm} \times 1.48 \mathrm{~mm}$. Middle 2 of the terminal spines on the apical joint of the 1st legs are distinctly bifid from the middle of their lengths as illustrated in Fig. 2, B. Lengths of egg tubes in Hamazima specimens are variable, ranging from one and a quarter times the carapace length to 
$7 / 10$.

In the female having very short abdomen and cordiform genital segment, which is fused with the 4th thoracic one, the new species is nearly allied to Caligus oviceps SHINO"), cordiventris SHIno, "atromaculatus Wilson"), parvus BASSETt-SMITH", minimus OTro"), balistae STEENSTRuP \& LÜTKEN ${ }^{5}$, and schistonyx WrLson ${ }^{6,8}$. It is distinguished from the first of them by the more powerful 2nd maxillipeds of the female, by the simple terminal claw of the male 2nd antennae, and by the different arrangement of spines on the 'male genital segment, from the second by the non-serrated spines on the first 2 exopodite joints of the 2nd legs and by the disposition of spines on the 4th legs, and from the third by the shape of the sternal fork, by the 3jointed 4th legs, and by the genital segment which is wider than long. The new species is less close to the rest of the named species, differences in the outline of the genital segment being greater. In this point, it resembles alatus HEEGAARD ${ }^{32}$ in both the sexes, but the segment is distinct from the 4th thoracic one in the female of the latier. The 2 species are different further in the constitution of the sternal fork and of the 2nd maxillipeds.

\section{References}

1. P. W. Bassett-Smith : Ann. Mag. Nat. Hist., (1) 1, 1-17 (1898).

2. A. Brian: Ann. Mus. Civ. Si. Nat., 57, 152-211 (1935).

3. .P. E. Heggaard : Ark. f. Zool., 34 A, no. 18, 1-37 (1943).

4. S. M. Shino : Rep. Eac. Fish., Pref. Univ. Mie, 1, 79-113 (1952).

5. J. J. S. Steenstrup \& C. F. Lürken: Videns. Selsk. Skr. 5te R., Naturh.-mathem., 5, 343 -432 (1861).

6. C. B. Wilsox : Proc. U. S. Nat. Mus., 28, 479-692 (1905).

7. …........... : Ibic., 44, 189-227 (1913).

8. .............. : Bull. U. S. Nat. Mus., 158, 1-633 (1932). 